Brit. J. vener. Dis. (1963), 39, 143.

\title{
TREATMENT OF EARLY SYPHILIS WITH PENICILLIN ALONE*
}

BY

\author{
F. J. G. JEFFERISS AND R. R. WILLCOX
}

St. Mary's Hospital, London

To-day few clinicians doubt the efficacy of penicillin as the sole curative agent in the treatment of syphilis, and the wide range of arsenical and bismuth preparations at one time available have virtually disappeared from the pharmaceutical market.

The first few sailors to be given penicillin for syphilis were treated by Mahoney, Arnold, and Harris (1943), which event was followed by numerous reports of phenomenal success on a wider scale $(e . g$. Sternberg and Leifer, 1947; and see Moore 1947). The difficulty created by the less successful results which were due to the varying amounts of the $G$ fraction present in the earlier amorphous penicillins (U.S. Public Health Service, 1946) was successfully resolved by the isolation and production of crystalline (benzyl) penicillin $G$ and by the introduction of repository preparations: penicillin in oil-beeswax (Romansky and Rittman, 1945), procaine penicillin (Buckwalter and Dickison, 1948), and procaine penicillin in oil with aluminium monostearate (PAM) and benzathine penicillin. The success of penicillin in the treatment of syphilis has since continued uninterrupted, and to-day there is no sign that $T$. palli$d u m$ is less sensitive to the antibiotic; allergic reactions, although occasionally troublesome in individual cases, offer no major obstacle to the routine treatment of the disease provided proper precautions are taken (W.H.O., 1960).

Acceptance of penicillin alone for the treatment of a chronic and serious disease like syphilis was much slower in Europe than in other parts of the world. In many centres for some years a course of old style neo-arsphenamine and bismuth was given in addition to penicillin. Then, as severe toxic reactions continued to occur with the arsenical compounds, these were omitted, and for a time treatment with penicillin was followed by a course of bismuth injections.

* Received for publication March 29, 1963.
Finally, the weakly treponemicidal metallic compound was also discarded and penicillin was used alone.

The therapeutic results have been very good. For example, Shafer, Wilton, and Price (1954), describing 961 cases, reported a cumulative re-treatment rate at 12 months of 8.2 per cent. in primary and 11.8 per cent. in secondary syphilis treated with penicillin: at 24 months the figures were $10 \cdot 8$ per cent. and $14 \cdot 6$ per cent. respectively. Helleström and Skog (1961) had only one failure in 91 cases of primary and secondary syphilis in which either procaine penicillin or PAM was used, and in this case only a very small dose had been given. Smith, Kamp, Olansky, and Price (1956) reported a cumulative re-treatment rate of only $5 \cdot 5$ to $7 \cdot 7$ per cent. of 321 patients given single injections of benzathine penicillin or of PAM. Excellent results were reported by Perdrup (1960) in 171 cases, some of which were followed for 10 years and more.

Although the therapeutic results have been excellent, re-treatment may be required in a few cases; in many of these the apparent failure is due to re-infection and not to relapse, for the syphilitic patient treated with penicillin is liable to re-infection sooner than in former times when treatment was protracted. Although the available criteria of re-infection are better in syphilis than in gonorrhoea (e.g. the appearance of a dark-field positive chancre at a new site while the serological findings are still negative in a patient previously treated for sero-positive early syphilis, coupled with a history of exposure with a person known to have infectious syphilis), these can only be applied to a proportion of cases. It has therefore been the general practice, in the assessment of the results of therapy, to refer to re-treatment rates without attempting to differentiate relapse from re-infection. This has sometimes resulted in an apparent improvement in the results of therapy with 
penicillin through the years, as the prevalence of early syphilis fell to low levels after World War II and re-infection from fresh sources became less likely. As syphilis is now becoming more prevalent in many countries, re-infections may likewise be expected to become more common.

\section{Present Investigations}

In earlier papers (McElligott, Jefferiss, and Willcox, 1948; Jefferiss, Willcox, and McElligott, 1951; Willcox, Jefferiss, and McElligott, 1958), the results of treating 744 cases of early syphilis with penicillin plus arsenic and/or bismuth compounds at St. Mary's Hospital were presented. The last of these three papers also included the results of treating 120 cases with penicillin alone, and in the present paper, this third series (Willcox and others, 1958), has been extended to 636 cases-making a total of 1,380 cases of early syphilis in this clinic treated with penicillin alone or in combination with other drugs.

Of the 636 patients who were given penicillin alone, 547 were male and 89 were female: 211 had sero-negative primary syphilis, 179 had sero-positive primary syphilis, 196 had secondary syphilis, and fifty had early latent syphilis in the first year of infection.

Type of Therapy.-The penicillin was given in a variety of ways. In 114 cases only 2.4 to 5 mega units was given, usually as repeated injections of benzyl penicillin, although seven patients in this group had one or two injections of benzathine penicillin and some were defaulting patients on longer schedules of treatment. In 231 cases $5 \cdot 1$ to 10 mega units was given in daily injections of procaine penicillin or of procaine penicillin in oil with aluminium monostearate (PAM): in 45 of this group 8 mega units or less was received on account of default. In 291 cases more than 10 mega units was given either as ten daily injections of aqueous procaine penicillin, or by using an additional ten twice-weekly injections of PAM after an initial daily course of aqueous procaine penicillin, or by using twice-weekly injections of PAM throughout.

Follow-up.-After treatment the patients were instructed to attend for clinical and serological examinations once a month for 6 months, quarterly for a year, and 6-monthly for a second year.

The follow-up rate achieved is shown in Table I: some 57.9 per cent. of cases were followed for 11 to 15 months or more, and $37 \cdot 4$ per cent. for 2 to $2 \frac{1}{2}$ years or more.

TABLE I

FOLLOW-UP

\begin{tabular}{|c|c|c|c|c|c|c|c|}
\hline \multirow{2}{*}{\multicolumn{2}{|c|}{ Type of Syphilis }} & \multirow{2}{*}{$\begin{array}{c}\text { Sero- } \\
\text { negative } \\
\text { Primary }\end{array}$} & \multirow{2}{*}{$\begin{array}{c}\text { Sero- } \\
\text { positive } \\
\text { Primary }\end{array}$} & \multirow{2}{*}{$\begin{array}{c}\text { Second- } \\
\text { ary }\end{array}$} & \multirow{2}{*}{$\begin{array}{c}\text { Early } \\
\text { Latent }\end{array}$} & \multicolumn{2}{|c|}{$\begin{array}{l}\text { Total } \\
\text { Cases }\end{array}$} \\
\hline & & & & & & No. & $\begin{array}{c}\text { per } \\
\text { cent. }\end{array}$ \\
\hline \multirow{2}{*}{ Sex } & $\begin{array}{l}\text { Male } \\
\text { Female }\end{array}$ & $\begin{array}{r}209 \\
2\end{array}$ & $\begin{array}{r}163 \\
59\end{array}$ & $\begin{array}{r}137 \\
59\end{array}$ & $\begin{array}{l}38 \\
12\end{array}$ & $\begin{array}{r}547 \\
89\end{array}$ & - \\
\hline & Total & 211 & 179 & 196 & 50 & 636 & $100 \cdot 0$ \\
\hline $\begin{array}{l}\text { Length } \\
\text { of } \\
\text { Follow- } \\
\text { up } \\
\text { (mths) }\end{array}$ & $\begin{array}{r}1-4 \\
5-7 \\
8-10 \\
11-15 \\
16-21 \\
22-30\end{array}$ & $\begin{array}{r}186 \\
165 \\
148 \\
134 \\
107 \\
98\end{array}$ & $\begin{array}{r}154 \\
137 \\
107 \\
95 \\
72 \\
59\end{array}$ & $\begin{array}{r}158 \\
138 \\
120 \\
106 \\
84 \\
69\end{array}$ & $\begin{array}{l}46 \\
39 \\
34 \\
33 \\
21 \\
12\end{array}$ & $\begin{array}{l}544 \\
479 \\
409 \\
368 \\
284 \\
238\end{array}$ & $\begin{array}{l}85 \cdot 5 \\
75 \cdot 3 \\
64 \cdot 3 \\
57 \cdot 9 \\
44 \cdot 7 \\
37 \cdot 4\end{array}$ \\
\hline
\end{tabular}

\section{Results of Therapy}

The results were excellent. Ignoring one female patient who had been treated for secondary syphilis and was re-treated 7 months later, while completely sero-negative (because she was pregnant), re-treatment was necessary within $2 \frac{1}{2}$ years for seventeen patients (only one of whom was female) i.e. $3 \cdot 1$ per cent. of those followed. The cumulative re-treatment rate at 22 to 30 months was $4 \cdot 42$ per cent. (Table II). Two of the seventeen re-treatments were required by one man who apparently had three infections during the period of study.

TABLE II

RESULTS OF THERAPY

\begin{tabular}{|c|c|c|c|c|c|c|c|}
\hline \multirow{2}{*}{$\begin{array}{l}\text { Length of } \\
\text { Follow-up } \\
\text { (mths) }\end{array}$} & \multirow{2}{*}{$\begin{array}{l}\text { No. of Patients } \\
\text { Followed }\end{array}$} & \multicolumn{4}{|c|}{ No. of Re-treatments } & \multirow{2}{*}{$\begin{array}{l}\text { Per cent. } \\
\text { Re-treated }\end{array}$} & \multirow[b]{2}{*}{$\begin{array}{l}\text { Cumulative } \\
\text { Per cent. }\end{array}$} \\
\hline & & $\underset{\text { Incident }}{\text { New Clinical }}$ & $\begin{array}{l}\text { Sero- } \\
\text { recurrence }\end{array}$ & Sero-resistance & Total & & \\
\hline $\begin{array}{r}\text { Less than } 1 \\
1-4 \\
5-7 \\
8-10 \\
11-15 \\
16-21 \\
22-30\end{array}$ & $\begin{array}{l}636 \\
544 \\
479 \\
409 \\
368 \\
284 \\
238\end{array}$ & $\begin{array}{l}-2 \\
4 \\
4 \\
1 \\
-\end{array}$ & $\begin{array}{l}- \\
\bar{Z} \\
2 \\
2\end{array}$ & $\begin{array}{l}\bar{z} \\
z \\
\bar{z} \\
-\end{array}$ & $\begin{array}{l}-\overline{2} \\
6 \\
4 \\
1 \\
2 \\
2\end{array}$ & $\begin{array}{l}- \\
0.37 \\
1.25 \\
0.98 \\
0.27 \\
0.71 \\
0.84\end{array}$ & $\begin{array}{l}-\overline{0} \\
1 \cdot 37 \\
2 \cdot 62 \\
2 \cdot 60 \\
3 \cdot 87 \\
4 \cdot 42\end{array}$ \\
\hline Totals & 544 & 11 & 4 & 2 & 17 & - & - \\
\hline
\end{tabular}


The two sero-recurrences at 22 to 30 months occurred at 25 and 28 months respectively, so that the cumulative re-treatment rate at 2 years was 3.58 per cent. In addition, re-treatment was also undertaken in four other cases, two for clinical reasons and two on serological grounds, for patients who returned after discharge 3 to $8 \frac{1}{2}$ years later. No serious allergic reaction to penicillin was noted in this series.

Serological Findings.-These were likewise impressive (Table III). The findings at the time of re-treatment in the re-treated cases are included in this Table, although most of the cases concerned were considered to be re-infections.

TABLE III

SEROLOGICAL FINDINGS IN SERO-POSITIVE CASES

\begin{tabular}{|c|c|c|c|c|c|}
\hline \multirow{2}{*}{$\begin{array}{c}\text { Length of } \\
\text { Follow-up } \\
\text { (mths) }\end{array}$} & \multirow{2}{*}{$\begin{array}{c}\text { Total } \\
\text { No. of Cases }\end{array}$} & \multicolumn{2}{|c|}{$\begin{array}{c}\text { Wassermann } \\
\text { Reaction Negative }\end{array}$} & \multicolumn{2}{|c|}{$\begin{array}{l}\text { V.D.R.L. Tests } \\
\text { Negative }\end{array}$} \\
\hline & & No. & per cent. & No. & per cent. \\
\hline $\begin{array}{r}\text { Less than } 1 \\
1-4 \\
5-7 \\
8-10 \\
11-15 \\
16-21 \\
22 \text { or More }\end{array}$ & $\begin{array}{l}425 \\
358 \\
314 \\
261 \\
244 \\
177 \\
140\end{array}$ & $\begin{array}{r}0 \\
272 \\
282 \\
245 \\
214 \\
171 \\
138\end{array}$ & $\begin{array}{r}0 \\
76 \cdot 0 \\
89 \cdot 9 \\
93 \cdot 9 \\
87 \cdot 7 \\
96 \cdot 6 \\
98 \cdot 6\end{array}$ & $\begin{array}{r}0 \\
155 \\
236 \\
223 \\
208 \\
164 \\
133\end{array}$ & $\begin{array}{r}0 \\
43 \cdot 0 \\
75 \cdot 2 \\
85 \cdot 4 \\
85 \cdot 2 \\
92 \cdot 7 \\
95 \cdot 0\end{array}$ \\
\hline
\end{tabular}

A complement-fixation (Wassermann) test and a flocculation (VDRL) test were made on each specimen of blood. In a few cases the Kahn test had been used instead of the latter. Sero-negativity was reached more quickly by the complement-fixation test, but by 22 months or more after treatment $98 \cdot 6$ per cent. of specimens tested were negative to the Wassermann test and 95 per cent. to the VDRL test.

Cerebrospinal Fluid Examinations.-These were made 9 months or more after treatment in 81 cases (78 males and 3 females); 41 of these patients had been treated for sero-negative primary syphilis, 25 for sero-positive primary syphilis, twelve for secondary syphilis, and three for early latent syphilis. The results were all normal except that in one case of sero-negative primary syphilis a protein content of $40 \mathrm{mg}$. per cent. with a colloidal gold reaction of 11111000 was found 18 months later with otherwise normal findings (cells 3 per cmm.; globulin normal; Wassermann reaction in cerebrospinal fluid and in blood negative).

\section{Cases Requiring Re-treatment}

These are related to the original stage of disease in Table IV, and to the dose of penicillin given for the original infection in Table $\mathrm{V}$.

TABLE IV

RE-TREATMENT RELATED TO STAGE OF DISEASE

\begin{tabular}{|c|c|c|c|c|c|}
\hline $\begin{array}{l}\text { Type of } \\
\text { Syphilis }\end{array}$ & No. & $\begin{array}{l}\text { No. } \\
\text { Followed }\end{array}$ & $\begin{array}{l}\text { No. } R e- \\
\text { treated } \\
\text { within } \\
2 \frac{1}{2} \text { years }\end{array}$ & $\begin{array}{l}\text { Per cent. } \\
\text { of those } \\
\text { Followed }\end{array}$ & $\begin{array}{l}\text { No. Re- } \\
\text { treated } \\
\text { after } \\
2 \frac{1}{2} \text { years }\end{array}$ \\
\hline $\begin{array}{l}\text { Sero-negative } \\
\text { Primary } \\
\text { Sero-positive }\end{array}$ & 211 & 186 & 6 & $3 \cdot 2$ & 1 \\
\hline $\begin{array}{l}\text { Primary } \\
\text { Secondary } \\
\text { Early Latent }\end{array}$ & $\begin{array}{r}179 \\
196 \\
50\end{array}$ & $\begin{array}{r}154 \\
158 \\
46\end{array}$ & $\begin{array}{l}2 \\
5 \\
4\end{array}$ & $\begin{array}{l}1 \cdot 3 \\
3 \cdot 2 \\
8 \cdot 7\end{array}$ & $\begin{array}{l}1 \\
1 \\
1\end{array}$ \\
\hline Total & 636 & 544 & 17 & $3 \cdot 1$ & 4 \\
\hline
\end{tabular}

The new conditions for which re-treatment was given (Table VI, overleaf) include four cases in which it was required after 3 years, for dark-field positive lesions ( 2 cases) or on serological grounds ( 2 cases). In ten cases, new chancres in different sites (one in the axilla) appeared, $T$. pallidum being found in nine; three had signs of secondary syphilis; six patients (one female) were re-treated for serorecurrence and two for sero-resistance, although in one of these latter cases the titre was already declining. Apart from these two cases of seroresistance it is our firm view that the great majority of cases (possibly all) in which re-treatment was required were due to re-infection. The high proportion showing chancres at new sites supports this view.

TABLE V

RE-TREATMENT RELATED TO DOSE OF PENICILLIN GIVEN FOR ORIGINAL INFECTION

\begin{tabular}{c|c|c|c|c|c}
\hline Dose (mega units) & $\begin{array}{c}\text { No. } \\
\text { Treated }\end{array}$ & $\begin{array}{c}\text { No. } \\
\text { Followed }\end{array}$ & $\begin{array}{c}\text { No. Re-treated } \\
\text { within 30 Months }\end{array}$ & $\begin{array}{c}\text { Per cent. Re-treated } \\
\text { within 30 Months of } \\
\text { those Followed }\end{array}$ & $\begin{array}{c}\text { No. Re-treated } \\
\text { after 30 Months }\end{array}$ \\
\hline $2 \cdot 4-5$ & 114 & 98 & 3 & $3 \cdot 1$ & -1 \\
$5 \cdot 1-8$ & 45 & 32 & 1 & $3 \cdot 4$ \\
$8 \cdot 1-10$ & 186 & 162 & 5 & - \\
$10 \cdot 1+$ & 291 & 252 & 5 & $2 \cdot 0$ & 3 \\
\hline Total & 636 & 544 & 17 & $3 \cdot 1$ & 4 \\
\hline
\end{tabular}


TABLE VI

CONDITION OF PATIENTS AT RE-TREATMENT

\begin{tabular}{|c|c|c|c|c|c|c|c|}
\hline Type of Syphilis & $\begin{array}{c}\text { TP+ : Sero- } \\
\text { negative }\end{array}$ & $\begin{array}{l}\text { TP+ : Sero- } \\
\text { positive }\end{array}$ & $\begin{array}{l}\text { TP not found: } \\
\text { Sero-positive }\end{array}$ & Secondary & $\begin{array}{l}\text { Sero- } \\
\text { recurrence }\end{array}$ & $\begin{array}{l}\text { Sero- } \\
\text { resistance }\end{array}$ & Total \\
\hline $\begin{array}{l}\text { Sero-negative Primary } \\
\text { Sero-positive Primary } \\
\text { Secondary } \\
\text { Early Latent }\end{array}$ & $\frac{4}{-}$ & $\begin{array}{l}1 \\
1 \\
1 \\
2\end{array}$ & $\frac{1}{-}$ & $\begin{array}{l}1 \\
1 \\
1 \\
-\end{array}$ & $\begin{array}{l}\overline{1} \\
2 \\
3\end{array}$ & $\frac{\bar{z}}{2}$ & $\begin{array}{l}7 \\
3 \\
6 \\
5\end{array}$ \\
\hline Total & 4 & 5 & 1 & 3 & 6 & 2 & 21 \\
\hline
\end{tabular}

\section{Homosexuals}

Another strong reason for this belief is the high proportion of extremely promiscuous homosexuals amongst those requiring re-treatment. No less than eleven of the sixteen male patients to whom re-treatment was given within $2 \frac{1}{2}$ years, and also all four of those re-treated after 3 years, were homosexuals admitting to very frequent promiscuous risks, one case being a typical example of 'pin-pong' infection. Thus no less than 75 per cent. of the males requiring re-treatment were homosexuals. Furthermore, one of the six re-treated heterosexual patients had been living, until the time of re-treatment, with a previously untreated infected female.

Of the twenty re-treated male cases, three arose in the years 1946-1950, two in the period 1951-1960, and no less than fifteen in the years 1961-1962. All of the re-treatments undertaken between 1946 and 1960 were in heterosexual patients, but all of those undertaken in 1961-1962 were in homosexuals.

There has recently been a marked rise in the numbers of patients attending the clinic with early syphilis. This rise has been mainly confined to male patients; the numbers in 1960-1962 were three times those in 1957-1959, whereas the smaller numbers of female cases only increased by one-half during this time.

There has been a rising proportion of known homosexuals among the male patients included in the study from 12 per cent. in the years 1954-1956 to 66.4 per cent. in $1957-1959$ and 65 per cent. in 1960-1962. This has been reflected also in the change in the male: female ratio of patients with early syphilis attending the clinic, from 3.3: 1 in 1954-1956 to no less than $8 \cdot 4: 1$ in $1960-1962$.

There is little doubt that the problem of homosexuals is greatest in London and the large cities, but the lengthening of the male: female ratio is also noted in the consolidated figures for the clinics of England and Wales (Ministry of Health, 1962) from $2 \cdot 6: 1$ in 1954-1956 to $4 \cdot 4: 1$ in 1960-1961 (Table VII), the most marked increase being between 1959 and 1960. Whether there is a general increase in homosexuality, or merely an increased or more rapid
TABLE VII

PROPORTION OF HOMOSEXUALS AND MALE : FEMALE RATIO

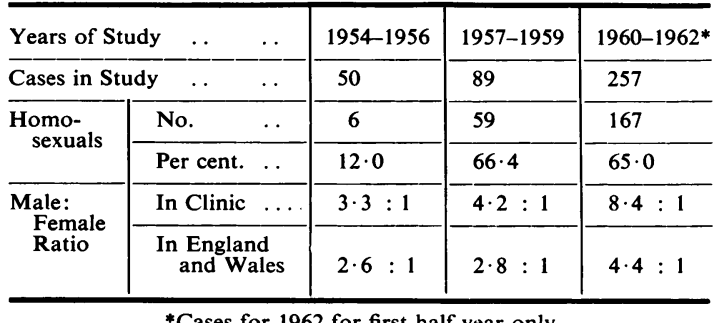

${ }^{*}$ Cases for 1962 for first half year only

dissemination of syphilis in homosexuals, is not entirely clear. There has been a significant increase in recent years of homosexual males with early syphilis contracting the disease for the second time; of 116 homosexuals attending with early syphilis in 1961-1962, no less than fifteen (12.9 per cent.) had been treated and/or observed for an early syphilitic infection in the same clinic in former years; but, of the $\mathbf{3 7 5}$ male patients with active early syphilis seen during the decade 1951-1960, there were no homosexuals who had previously been treated for early syphilis in the same clinic.

Comparison of Results obtained with Penicillin Alone and with Penicillin in Combination with Other Drugs

Table VIII (opposite), shows a comparison between the results obtained with penicillin alone, penicillin and bismuth, and penicillin, arsenic, and bismuth.

The apparently superior results with penicillin alone are considered to be due to the lessened risk of re-infection since syphilis became less prevalent, than in the days when combined therapy was used. If the present recrudescence in the prevalence of syphilis continues, however, differences may later become less marked.

\section{Summary and Conclusions}

(1) Penicillin alone has been used in the treatment of early syphilis at St Mary's Hospital since 
TABLE VIII

COMPARISON OF RESULTS OF TREATMENT BY THREE METHODS

\begin{tabular}{|c|c|c|c|c|}
\hline \multicolumn{2}{|c|}{ Schedule of Treatment } & $\begin{array}{l}\text { Penicillin } \\
+ \text { Arsenic } \\
\text { and } \\
\text { Bismuth }\end{array}$ & $\begin{array}{l}\text { Penicillin } \\
+ \text { Bismuth }\end{array}$ & $\begin{array}{l}\text { Penicillin } \\
\text { Alone }\end{array}$ \\
\hline \multicolumn{2}{|c|}{ Number Treated. } & 561 & 183 & 636 \\
\hline \multirow{2}{*}{$\begin{array}{l}\text { No. Followed } \\
\text { for One Year } \\
\text { or More } . \\
\end{array}$} & No. ... & 307 & 76 & $368 *$ \\
\hline & Per cent. & $54 \cdot 5$ & $41 \cdot 5$ & $57 \cdot 9^{*}$ \\
\hline \multicolumn{2}{|c|}{ No. of Re-treatments } & 22 & 7 & 17 \\
\hline \multicolumn{2}{|c|}{$\begin{array}{l}\text { Percentage Re-treatments of } \\
\text { Those Followed for One } \\
\text { Year or More .. }\end{array}$} & $7 \cdot 2$ & $9 \cdot 2$ & $4 \cdot 6$ \\
\hline
\end{tabular}

*Followed 11 months or more

1951. Some 744 cases in which penicillin and bismuth, and penicillin, arsenic, and bismith were used, have previously been reported. This paper reports the results in a further 636 cases in which penicillin alone was used.

(2) Of the 636 patients given penicillin alone, $57 \cdot 9$ per cent. were followed for 11 to 15 months or more and re-treatment was required within 30 months in seventeen-a cumulative retreatment rate of 4.42 per cent. In two cases re-treatment was for sero-resistance, in four for sero-recurrence, and in eleven for new clinical lesions. Although no attempt has been made to differentiate relapses from re-infection, it is considered likely, for a number of reasons stated, that in the great majority of these cases re-treatment was required because of re-infection rather than because of relapse or persistence of the original infection.

(3) The serological findings were generally satisfactory, sero-negativity to the Wassermann test being reached at 22 months or more in 98.6 per cent. and to the VDRL test in 95.0 per cent. In addition, follow-up examinations of the cerebrospinal fluid were satisfactory (apart from one case with dubious findings) in 81 patients tested.

(4) It is suggested that, with the increasing numbers of male homosexuals with early syphilis, re-infections with syphilis are again becoming more common.

(5) The results of treatment of early syphilis with penicillin alone have been excellent. The addition of other agents is neither necessary nor desirable.
Our gratitude is expressed to the staff of the clinic at St. Mary's who have helped in this study, particularly Dr N. Rosedale.

\section{REFERENCES}

Buckwalter, F. H., and Dickison, H. L. (1948). J. Amer. pharm. Ass. (Sci. Ed.), 37, 472.

Helleström, S., and Skog, E. (1961). World Health Organization Working Document. WHO/VDT/ 288.

Jefferiss, F. J. G., Willcox, R. R., and McElligott, G. L. M. (1951). Lancet, 1, 83.

McElligott, G. L. M., Jefferiss, F. J. G., and Willcox, R. R. (1948). Brit. J. vener. Dis., 24, 45.

Mahoney, J. F., Arnold, R. C., and Harris, A. (1943). Vener. Dis. Inform., 24, 355.

Ministry of Health (1962). "Annual Report of Chief Medical Officer for 1961", Part II, p. 233. Appendix C. Cmnd 1856. H.M.S.O., London.

Moore, J. E. (1947). "Penicillin in Syphilis". Thomas, Springfield, IIl.

Perdrup, A. (1960). Acta derm.-venereol. (Stockh.), 40, 340.

Romansky, M. J., and Rittman, G. E. (1945). New Engl. J. Med., 233, 577.

Shafer, J. K., Usilton, L. J., and Price, E. V. (1954). Bull. Wld Hlth Org., 10, 563.

Smith, C. A., Kamp, M., Olansky, S., and Price, E. V. (1956). Ibid., 15, 1087.

Sternberg, T. H., and Leifer, W. (1947). J. Amer. med. Ass., 133, 1.

United States Public Health Service (1946). Ibid., 131, 271.

Willcox, R. R., Jefferiss, F. J. G., and McElligott, G. L. M. (1958). Brit. J. vener. Dis., 34, 14.

World Health Organization (1960). Expert Committee on Venereal Infections. Fifth Report. Techn. Rep. Ser. No. 190 , p. 45-50.

La syphilis précoce traitée par la pénicilline seule RÉSUMÉ

(1) La pénicilline seule a été donnée aux malades atteints de syphilis précoce à St. Mary's Hospital depuis 1951. 744 cas traités par la pénicilline avec le bismuth, et par la pénicilline avec l'arsenic et le bismuth, ont déjà été rapportés. Cette communication présente les résultats obtenus pour 636 malades qui reçurent la pénicilline seule.

(2) Sur 636 malades, $57,9 \%$ furent suivis pendant 11 à 15 mois ou plus. Il y eut $17(4,42 \%)$ récidives au cours de 30 mois-deux cas de séro-resistance, quatre cas de rechute sérologique, et onze cas de lésions nouvelles. On n'a pas délimité les rechutes et les ré-infections, mais il paraît que la ré-infection fut plus souvent la raison de la récidive.

(3) La plupart des examens sérologiques furent négatifs. $\mathrm{La}$ réaction Wassermann devint négative après 22 mois dans $98,6 \%$ et le test V.D.R.L. dans $95 \%$ des cas. Le liquide céphalo-rachidien fut normal dans 81 cas examinés (sauf un douteux). 
(4) Il paraît que l'augmentation du nombre des hommes homosexuels atteints de syphilis précoce est la cause de la récrudescence de nouvelles infections.
(5) Les résultats du traitement de la syphilis précoce par la pénicilline seule sont si bons que l'addition de n'importe quel médicament n'est pas du tout nécessaire. 